\title{
Analysis of Minimally Disruptive Brief Pumping Tests of Domestic Wells Completed in Bedrock in the Appalachian Plateau of New York
}

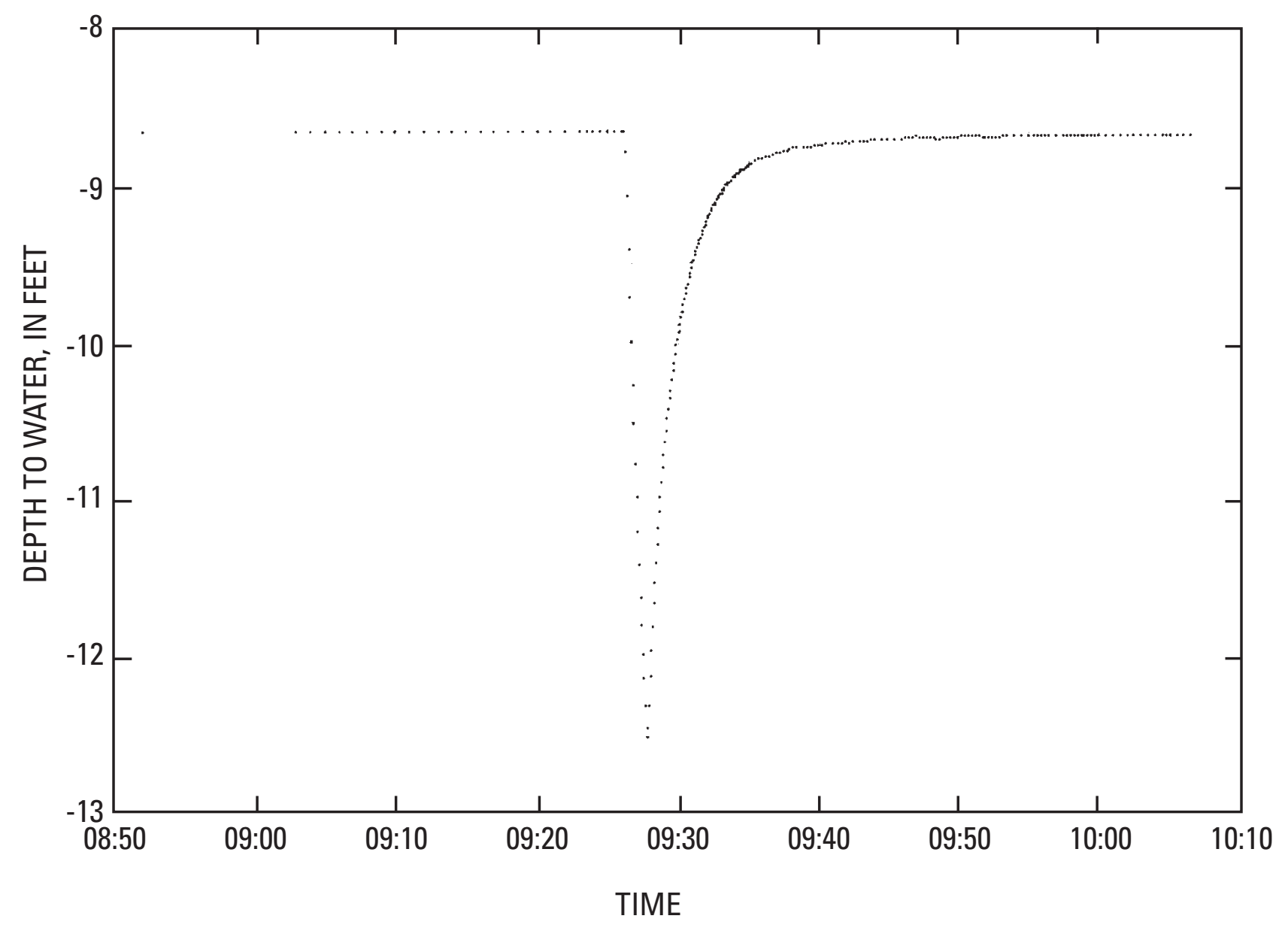

Open-File Report 2004-1276

U.S. Department of the Interior

U.S. Geological Survey 
Cover. Graph showing all measurements of depth to water below top of well casing obtained during test 107b (one of several tests reported in table 1). 


\section{Analysis of Minimally Disruptive Brief Pumping Tests of Domestic Wells Completed in Bedrock in the Appalachian Plateau of New York}

By Allan D. Randall and Kate Klusman

Open-File Report 2004-1276 


\title{
U.S. Department of the Interior \\ Gale A. Norton, Secretary \\ U.S. Geological Survey \\ Charles G. Groat, Director
}

\author{
U.S. Geological Survey, Reston, Virginia: 2004 \\ For additional information about this report write to: \\ U.S. Geological Survey \\ 425 Jordan Road \\ Troy, NY 12180 \\ Email: askny@usgs.gov \\ World Wide Web: http://ny.usgs.gov/
}

For more information about the USGS and its products:

Telephone: 1-888-ASK-USGS

Any use of trade, product, or firm names in this publication is for descriptive purposes only and does not imply endorsement by the U.S. Government.

Although this report is in the public domain, permission must be secured from the individual copyright owners to reproduce any copyrighted materials contained within this report.

Randall, A.D., and Klusman, Kate, 2004, Analysis of minimally disruptive brief pumping tests of domestic wells completed in bedrock in the Appalachian Plateau of New York: U.S. Geological Survey, Open-File Report 2004-1276, 8 pages. (Available online only, at http://ny.usgs.gov) 


\section{Contents}

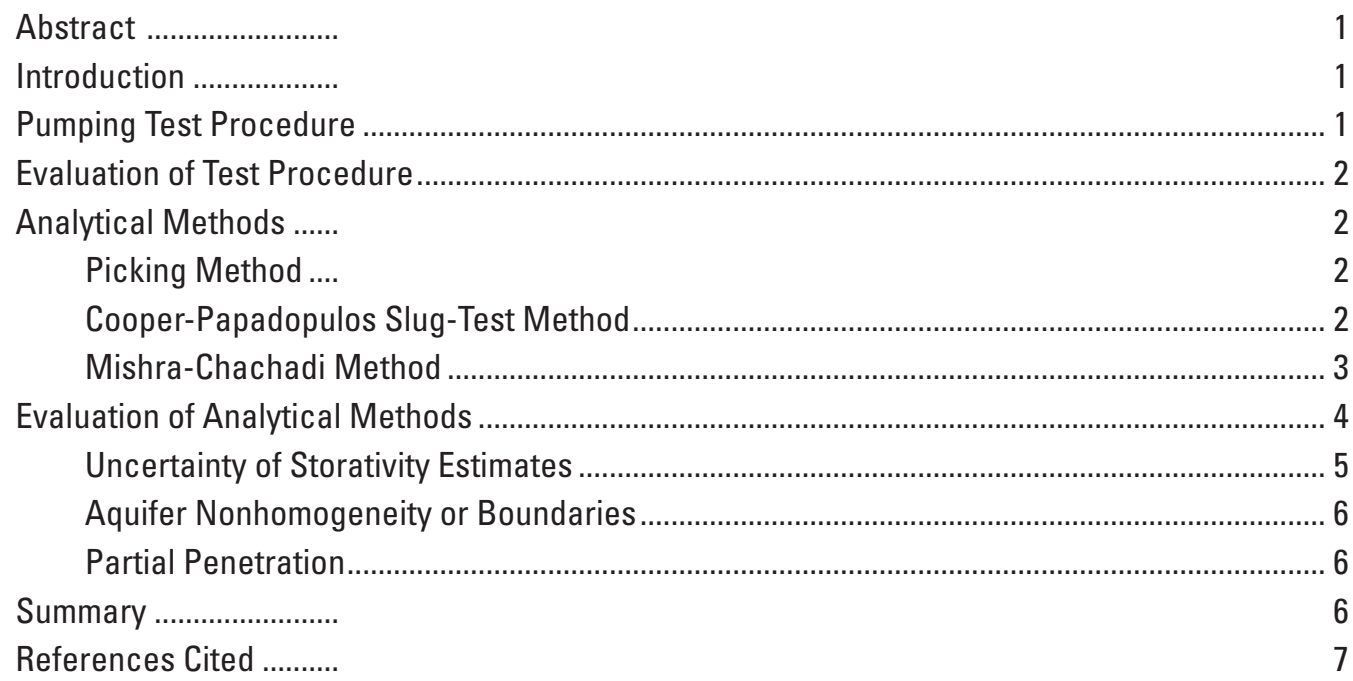

\section{Figures}

1. Example of how an extrapolated recovery curve was used to estimate the theoretical time of removal of a slug that would have generated the same recovery curve

2. Data from test 130, matched to the set of type curves by Mishra and Chachadi (1985) for $\alpha=0.01$

3. Comparison of transmissivity values from PICKINGmodel to those calculated from Cooper-

Papadopulos slug-test method and Mishra and Chachadi method 6

\section{Tables}

1. Transmissivity and storage coefficients as calculated from pumping tests of 26 bedrock wells in the Appalachian Plateau of New York by three computational methods, in metric units.

1A. Transmissivity and storage coefficients as calculated from pumping tests of 26 bedrock wells in the Appalachian Plateau of New York by three computational methods, in English units 


\section{Conversion Factors and Abbreviations}

\begin{tabular}{|c|c|c|}
\hline Multiply & By & To obtain \\
\hline \multicolumn{3}{|c|}{ Length } \\
\hline millimeter $(\mathrm{mm})$ & 0.03937 & inch (in.) \\
\hline meter $(\mathrm{m})$ & 3.281 & foot $(\mathrm{ft})$ \\
\hline \multicolumn{3}{|c|}{ Volume } \\
\hline liter $(\mathrm{L})$ & 0.2642 & gallon (gal) \\
\hline \multicolumn{3}{|c|}{ Pressure } \\
\hline $\begin{array}{l}\text { kilogram per square centimeter } \\
\left(\mathrm{kg} / \mathrm{cm}^{2}\right)\end{array}$ & 14.22 & pounds per square inch $\left(\mathrm{lb} / \mathrm{in}^{2}\right)$ \\
\hline \multicolumn{3}{|c|}{ Specific capacity } \\
\hline $\begin{array}{l}\text { liter per minute per meter } \\
{[(\mathrm{L} / \mathrm{min}) / \mathrm{m}]}\end{array}$ & 0.0805 & $\begin{array}{l}\text { gallon per minute per foot } \\
{[(\mathrm{gal} / \mathrm{min}) / \mathrm{ft}]}\end{array}$ \\
\hline \multicolumn{3}{|c|}{ Transmissivity* } \\
\hline meter squared per day $\left(\mathrm{m}^{2} / \mathrm{d}\right)$ & 10.76 & foot squared per day $\left(\mathrm{ft}^{2} / \mathrm{d}\right)$ \\
\hline
\end{tabular}

*Transmissivity: The standard unit for transmissivity is cubic meters per day per square meter times meters of aquifer thickness $\left[\left(\mathrm{m}^{3} / \mathrm{d}\right) / \mathrm{m}^{2}\right] \mathrm{m}$. In this report, the mathematically reduced form, meter squared per day $\left(\mathrm{m}^{2} / \mathrm{d}\right)$, is used for convenience. 


\title{
Analysis of Minimally Disruptive Brief Pumping Tests of Domestic Wells Completed in Bedrock in the Appalachian Plateau of New York
}

\author{
By Allan D. Randall and Kate Klusman
}

\begin{abstract}
One normal episode of pump operation in domestic wells drilled into bedrock in New York typically lasts about 1 minute and lowers the water level about 1 meter. Measurement of water levels in the pumped well before and during pumping and recovery can be completed in 2 to 3 hours and requires negligible disturbance of the well, so can be easily arranged. Such a test involves less turbulent flow or well loss than longer tests, and can be conveniently analyzed by a new computer program. Tests of 25 wells completed in shale, siltstone, or sandstone in the Appalachian Plateau of New York have been analyzed by this program and by two alternative methods, all of which yield similar transmissivity values and are equally insensitive to storativity.
\end{abstract}

\section{Introduction}

This paper describes a procedure for conducting very brief pumping tests, comparable to slug tests but more readily applied to domestic wells. The field procedure has been applied to about 50 wells completed in fractured shale, siltstone, and (or) sandstone bedrock in the Appalachian Plateau of New York. The paper goes on to report on analyses of 25 tests by a new computer program (Klusman, 2004) and validation by two other methods.

\section{Pumping Test Procedure}

Data collection includes three steps:

1. Monitor the non-pumping water level for about an hour, primarily to define the trend (typically still recovering from pumping earlier in the day) but also to detect possible interference from neighboring wells; such interference might warrant rescheduling the test or negotiation with neighbors.

2. Cause the pump to operate for its normal cycle, which typically will draw the water level down 0.5 to 1.5 meters in 0.5 to 1.5 minutes.

3. Obtain frequent water-level measurements during pumping and for at least 30 minutes of recovery — ideally at a 1 -second interval for the first few minutes and progressively less often thereafter.

The entire test, including setup and teardown, can be accomplished in about 2.5 hours. If feasible, the test should be scheduled for a day when withdrawals early in the day will be small (no laundry) and little water will be needed during the test period. If the house will be occupied during the test, turn off power to the pump upon arrival, restore power when ready for step 2 , then turn it off again so that occupants can use modest amounts of water without risk of prematurely terminating the recovery. If the house is unoccupied, monitor water-level trends, then run water from an outside faucet until the pump starts. If the pressure tank is very small or waterlogged, run water from one or two faucets wide open to ensure continuous pump operation for about one minute.

In most tests analyzed for this paper, water levels were recorded with a pressure transducer placed 3 meters below the initial water level. Meanwhile, frequent manual measurements were made with an electric tape to enable correction for settling of the transducer cable and possible logger drift. A few tests were done with only manual water-level measurements. The lower three meters of transducer cable and electric tape were briefly submerged in bleach solution after each test, to prevent transfer of biota from well to well. Water-level recovery was generally recorded for 1 to 4 hours, but the first 30 minutes of recovery data were sufficient for all analytical procedures described in this paper. The volume of water discharged was not measured because pressure-tank pressures at the start and end of pumping were unequal, so measured discharge could not be equated to withdrawal from the well. However, the volume withdrawn could be calculated from (a) the known casing radius and maximum drawdown, 
supplemented by (b) the inflow during pumping, estimated from specific capacity as described farther on.

\section{Evaluation of Test Procedure}

The test procedure described above has two principal advantages: (1) The test is easily accomplished by one investigator. Most homeowners are willing to cooperate because inconvenience is minimal, nothing is poured into the well (as would be done in slug tests), and the only stress on the well is that imposed several times each day by the pump's normal cycle. Results could be useful to the owner in the future if a change in well performance were suspected, because the test procedure and analysis could be replicated for comparison. The one risk is that the pressure transducer or electric tape might snag in the electric power cable, requiring that the pump be pulled to remove it. (2) The test imposes only a modest stress on the aquifer, far less than the typical driller's test; therefore, the laminar flow assumed by analytical equations is more likely to prevail in bedrock fractures. To the extent that flow is indeed laminar, well loss should be slight. Results are not suitable for estimating maximum well yield because the well loss and dewatering of fractures that accompany large drawdowns could severely reduce specific capacity. Transmissivity values computed from these tests should be suitable for comparing differing terranes and for estimating flow under natural gradients, including flow through bedrock to valley-fill aquifers.

The two main limitations of this test procedure are those common to all short-term, single-well tests in fractured bedrock: (1) Methods available for data analysis do not describe the actual flow of water through a few fractures amid generally impermeable bedrock, but rather describe idealized flow through an equivalent homogenous porous medium, and (2) results apply only to a small volume of rock around each well. If median aquifer properties and pumping data from this study are inserted in the Theis solution (Freeze and Cherry, 1979, p. 317), a drawdown of 3 millimeters is predicted at a radial distance of only 4.25 meters from the pumped well.

\section{Analytical Methods}

Nearly all tests were analyzed by two methods - the widely-used slug-test procedure of Cooper and others (1967), which could be applied to recovery after brief pumping by extrapolating the test data, and the method of Picking (1994) as modified and automated by Klusman (2004), which is designed to analyze recovery after an episode of pumping and accounts for the length of that episode. Half of the tests were also analyzed by a third method, that of Mishra and Chachadi (1985), which also assumes an episode of pumping and requires matching type curves to water levels during the pumping as well as recovery. All three methods represent radial flow through a porous medium; equations applicable to flow through one or more discrete fractures require longer tests, negligible well-bore storage, and (or) observation wells (Gernand and Heidtman, 1997, and references therein; Kruseman and deRidder, 1990, p. 249-274).

\section{Picking Method}

Picking (1994) presented a procedure for calculating aquifer transmissivity and storage by analyzing waterlevel recovery in a pumped well following a brief period of pumping at an unknown constant rate. The only data required are the radius of the well, the times when pumping started and stopped, and a series of water-level measurements at known times thereafter. Klusman (2004) wrote a computer program termed PICKINGmodel that automates Picking's method by directly calculating a complex mathematical function rather than relying on manual interpolation between values of that function in a lookup table. The theoretical basis, application, and limitations of this procedure are described by Klusman (2004) and are not repeated here. The new computer program and supporting documentation have been posted on the web (Klusman and Randall, 2004).

\section{Cooper-Papadopulos Slug-Test Method}

A widely used curve-matching procedure for analysis of slug tests was presented by Cooper and others (1967) and Papadopulos and others (1973); see also Kruseman and deRidder (1990). Water-level measurements made after the instantaneous removal or addition of a known volume of water are used to plot ht/ho against $\mathrm{t}$, where ho is initial displacement of the water level, and ht is residual displacement at time t. The data curves are matched to an array of type curves for $\alpha$ values ranging from $1 \mathrm{E}-1$ to $1 \mathrm{E}-10$. The symbol $\alpha$ represents Storage Coefficent (S) multiplied by the square of the ratio of the radius of the well within the water-yielding unit to the radius of the casing within which water levels are measured. (In all tests analyzed for this paper, $\alpha=S$ because the well radius in bedrock is the same as the casing radius.)

The pumping tests reported in this paper, although brief, did not remove water instantaneously, but the water levels that would have resulted from an instantaneous withdrawal could be reconstructed by the following procedure:

1. Specific capacity was calculated from the rate of water-level rise during recovery. Specific capacity invariably decreased as time and water level increased. Average specific capacity during the first 15 to 60 seconds of recovery was assumed to approximate specific capacity during pumping.

2. Volume of inflow during pumping was calculated by applying specific capacity to drawdown during successive 
increments of pumping, and was converted to an equivalent vertical distance within the well.

3. The vertical distance calculated in step 2 was added to the depth to water at the instant the pump stopped, to estimate the depth to water that would have resulted from removal of a slug of the same total volume.

4. The recovery curve was extrapolated backward in time until it intersected the depth to water calculated in step 3, thereby estimating the time at which instantaneous removal of the calculated volume would have produced the observed recovery curve (fig. 1). The back-extrapolation is inherently subjective, even when guided by auxiliary graphs (Klusman, 1999). However, if the early values of ht/ho and $t$ resulting from our initial back-extrapolation departed from a CooperPapadopulos type curve that later data points matched, a slight, plausible revision in the back-extrapolation would generally bring the early values into agreement.

The uncertainty in transmissivity resulting from reconstruction of a theoretical slug is negligible in tests where calculated inflow volume is less than 10 percent of total withdrawal, but would be significant in tests where large inflows occur from highly permeable formations.

\section{Mishra-Chachadi Method}

Mishra and Chachadi (1985) derived, by discretekernel analysis, five sets of type curves that depict both drawdown and recovery in wells of finite diameter. The five sets represent individual $\alpha$ values ranging from $1 \mathrm{E}-1$ to $1 \mathrm{E}-$ 6. Booth (1988) clearly described the use of this method to calculate transmissivity and storage from tests of domestic

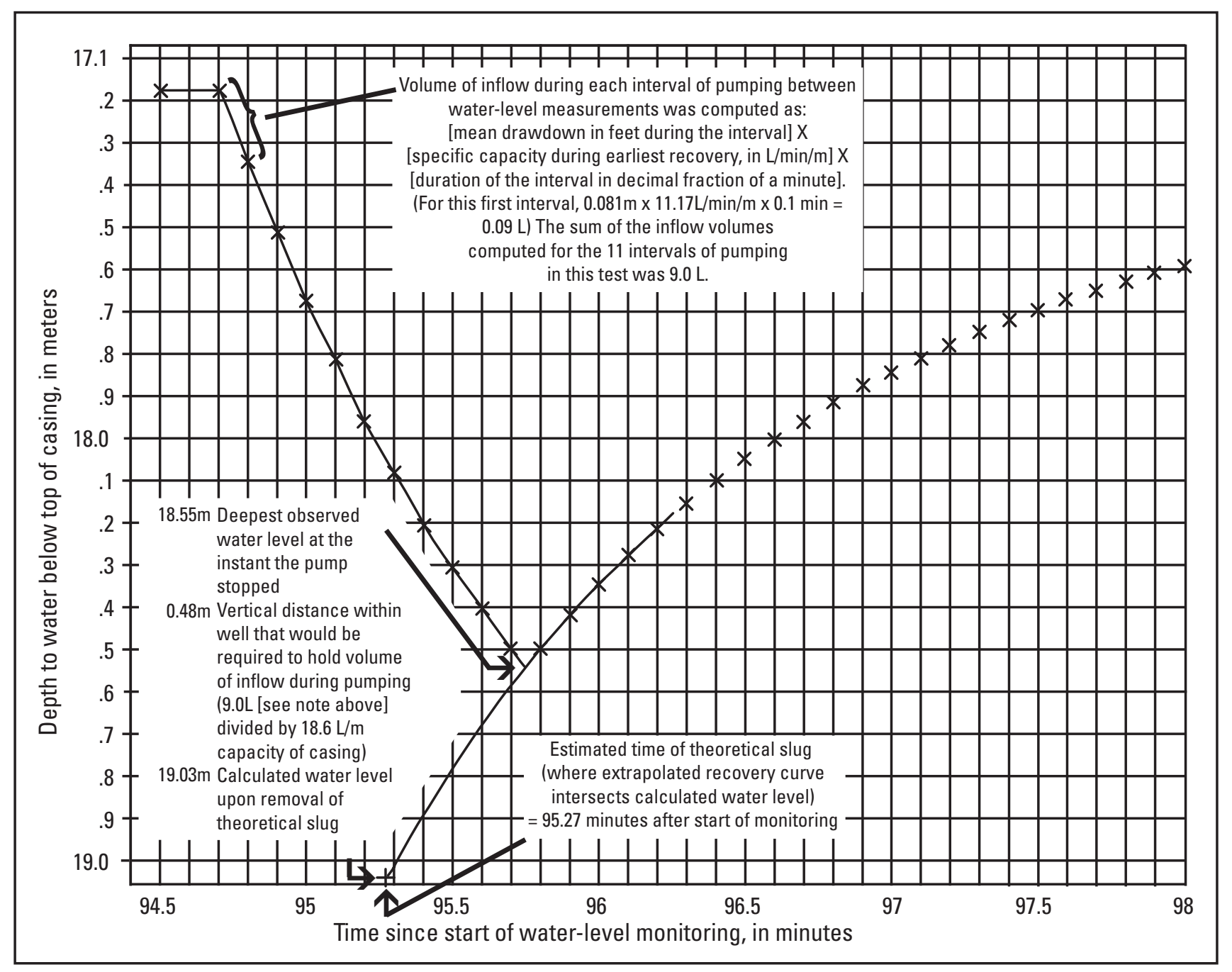

Figure 1. Example of how an extrapolated recovery curve was used to estimate the theoretical time of removal of a slug that would have generated the same recovery curve. 


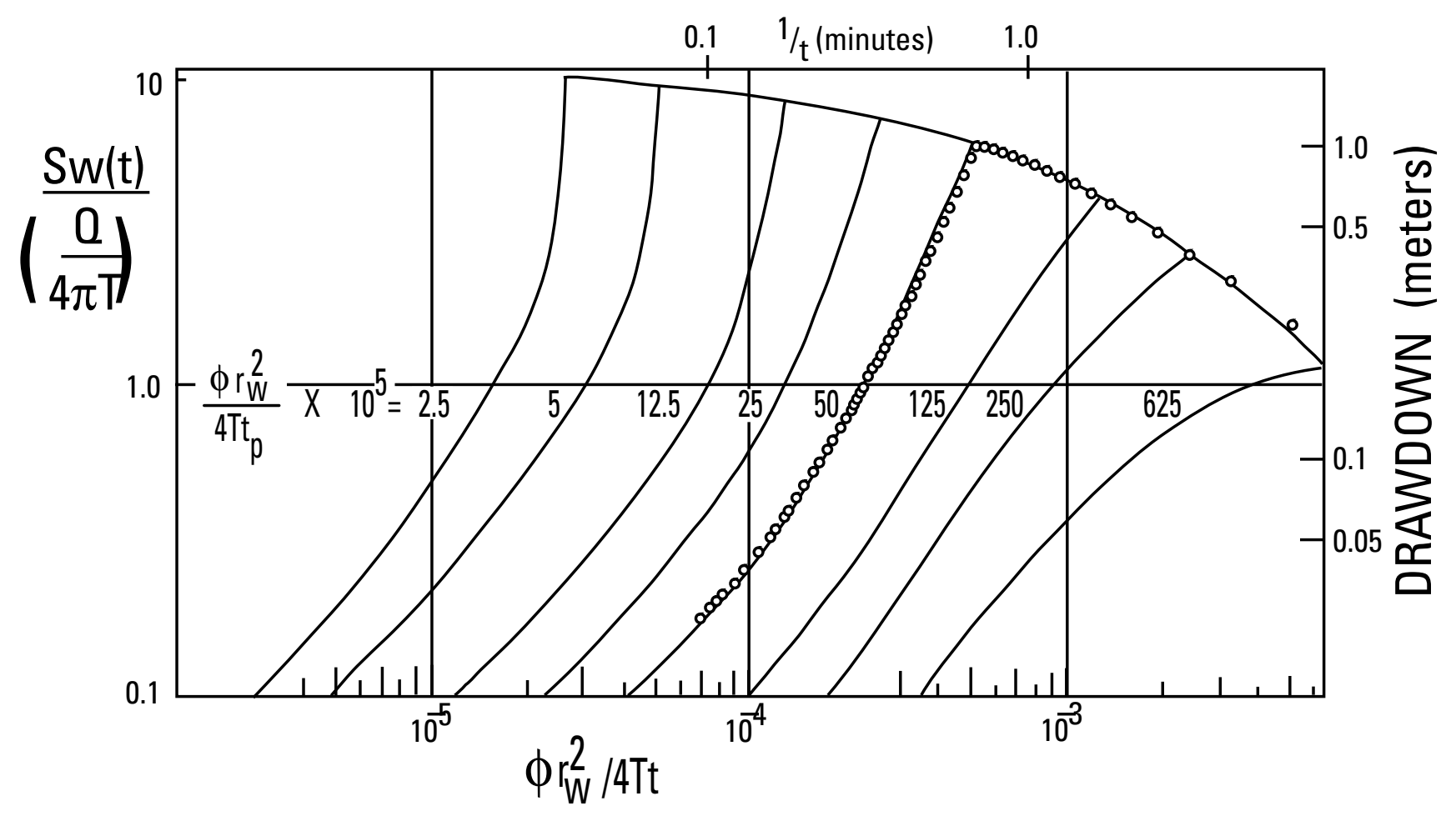

Figure 2. Data from test 130, matched to the set of type curves by Mishra and Chachadi (1985) for $\alpha=0.01$.

bedrock wells in the Appalachian Plateau of Pennsylvania, in which each well was pumped for only 2 to 5 minutes. To apply this method, drawdown during the pumping and recovery phases of tests is plotted on log-log paper versus $1 / t$, where $t$ is time since start of pumping, and matched to the published type curves, which for this study were enlarged on a copy machine to the scale of the graph paper (fig. 2). Mishra and Chachadi (1985) provide three alternative equations for estimation of transmissivity and storage; only the median results are reported in table 1 . One of these equations requires the (presumed constant) pumping rate; this was calculated as the total volume withdrawn (as estimated in step 3 of the Cooper-Papadopulos procedure) divided by the known duration of pumping. In tests of relatively productive wells where more than 40 percent of total withdrawal was derived from concurrent inflow, this equation tended to generate smaller transmissivity values than the other two equations, which suggests that estimates of inflow from specific capacity were too low.

\section{Evaluation of Analytical Methods}

All three methods are based on similar assumptions and on the mathematical formulation of Papadopulos and Cooper (1967); see also Cooper and others (1967). All yielded similar values of transmissivity (table 1; fig. 3). Regression analyses of the relations in figure 3 yielded the following equations: $\begin{array}{ll}\log \left(\mathrm{T}_{\text {Picking }}\right)=-0.0587+1.0555 \log \left(\mathrm{T}_{\text {Cooper }}\right) & \mathrm{R}^{2}=0.95 \\ \log \left(\mathrm{T}_{\text {Picking }}\right)=-0.345+1.2042 \log \left(\mathrm{T}_{\text {Mishra-Chachadi }}\right) & \mathrm{R}^{2}=0.94\end{array}$

In both equations, transmissivity $(\mathrm{T})$ is in $\mathrm{m}^{2} /$ day, slope was defined with a standard error of less than 0.1 , and intercepts were only weakly indicated to be different from zero. The Mishra-Chachadi method would be more useful if type curves were published at a larger scale (or as tabulated numerical values) and incorporated a wider range of curve parameters within each set and additional sets representing more $\alpha$ values. The Cooper-Papadopulos method, as modified for this paper, incorporates more subjective judgements than the PICKINGmodel, and tended to yield smaller values of storativity; however, it offers type curves for $\alpha$ values as small as $1 \mathrm{E}-10$, a wider range than the PICKINGmodel.

The PICKINGmodel and Mishra-Chachadi methods assume that the pumping rate is constant, which was not strictly true in this study because the pump discharged into a pressure tank whose pressure would have risen during the pumping episode, typically from 2.1 to 3.5 kilograms per square centimeter. Median static water level in the wells tested was about 12 meters below land surface; therefore, pumps were typically working against a total head that increased from about 33 meters to about 49 meters of water. According to performance curves for $1 / 2$-horsepower submersible pumps currently offered by one manufacturer, this increase in total head would decrease pump output only 7 percent, which seems small enough to ignore. 


\section{Uncertainty of Storativity Estimates}

All three methods are rather insensitive to storativity. The shapes of the type curves for successive $\alpha$ values are so similar that many data sets can be matched reasonably well to type curves that differ in $\alpha$ by 1 or 2 orders of magnitude. Furthermore, although storativity values estimated by the three different methods agreed for many tests, they differed by several orders of magnitude for others (table 1). A few seem implausibly large for fractured shale or fine sandstone of presumably low intergranular porosity. Tiedeman and Hsieh
(2001), who applied numerical rather than analytical models to tests of wells penetrating fractured bedrock, observed that open-well tests yielded transmissivity values similar to those calculated from packer tests that isolated individual horizontal fractures, whereas storativity estimates varied widely because some models compensated for their oversimplification of aquifer nonhomogeneity by altering storativity. Thus, although storativity values from these tests may be qualitatively interpretable, they should not be treated as an accurate representation of the local bedrock.

Table 1. Transmissivity and storage coefficients as calculated from pumping tests of 26 bedrock wells in the Appalachian Plateau of New York by three computational methods, in metric units.

$\left[\mathrm{m}^{2} / \mathrm{d}\right.$, meters s

\begin{tabular}{|c|c|c|c|c|c|c|c|}
\hline \multirow[b]{2}{*}{ Test * } & \multicolumn{3}{|c|}{ Transmissivity, in $\mathrm{m}^{2} / \mathrm{d}$} & \multicolumn{3}{|c|}{ Storage coefficient } & \multirow{2}{*}{$\begin{array}{c}\text { Specific } \\
\text { capacity, in } \\
(\mathrm{L} / \mathrm{min}) / \mathrm{m}\end{array}$} \\
\hline & $\begin{array}{l}\text { PICKING } \\
\text { model }^{a}\end{array}$ & $\begin{array}{c}\text { Cooper \& } \\
\text { Papadopulos }\end{array}$ & $\begin{array}{c}\text { Mishra \& } \\
\text { Chachadi }\end{array}$ & $\begin{array}{l}\text { PICKING } \\
\text { model }^{a}\end{array}$ & $\begin{array}{c}\text { Cooper \& } \\
\text { Papadopulos }{ }^{\mathrm{b}}\end{array}$ & $\begin{array}{c}\text { Mishra \& } \\
\text { Chachadi }\end{array}$ & \\
\hline 1 & 3.4 & 5.9 & -- & $1 \mathrm{E}-2$ & $1 \mathrm{E}-4$ & -- & 6.1 \\
\hline 2 & .68 & 1.6 & -- & $1.5 \mathrm{E}-1$ & $1 \mathrm{E}-2$ & -- & 3.5 \\
\hline 3 & 33. & 36 & -- & $1 \mathrm{E}-7$ & $1 \mathrm{E}-7$ & -- & 17 \\
\hline 101 & 2.3 & 2.4 & -- & $1 \mathrm{E}-3$ & $1 \mathrm{E}-3$ & -- & 3.0 \\
\hline 103 & 48 & 140 & -- & $1 \mathrm{E}-2$ & $1 \mathrm{E}-10$ & -- & 39 \\
\hline 105 & 15 & 20 & -- & $1 \mathrm{E}-5$ & 1E-7 & -- & 9.9 \\
\hline 106 & 14 & 22 & -- & $1 \mathrm{E}-4$ & $1 \mathrm{E}-7$ & -- & 11 \\
\hline $107 \mathrm{~b}$ & 13 & 11 & -- & $1 \mathrm{E}-4$ & $1 \mathrm{E}-3$ & -- & 11 \\
\hline 108 & 5.4 & 5.1 & -- & $1 \mathrm{E}-5$ & $1 \mathrm{E}-5$ & -- & 4.0 \\
\hline $109 \mathrm{~b}$ & 12 & 12 & -- & $1 \mathrm{E}-2$ & $1 \mathrm{E}-2$ & -- & 16 \\
\hline $110 \mathrm{~b}$ & 1.6 & 2.8 & -- & $5 \mathrm{E}-1$ & $1 \mathrm{E}-1$ & -- & 12 \\
\hline 115 & 1.8 & 4.3 & -- & $7 \mathrm{E}-2$ & $1 \mathrm{E}-3$ & -- & 5.0 \\
\hline 116 & 1.4 & 1.7 & -- & $4 \mathrm{E}-3$ & $1 \mathrm{E}-3$ & -- & 2.7 \\
\hline 127 & 24 & 14 & 33 & $>5 \mathrm{E}-1$ & $5 \mathrm{E}-1$ & $1 \mathrm{E}-1$ & 53 \\
\hline $127 \mathrm{~b}$ & 20 & 15 & -- & $5 \mathrm{E}-1$ & $5 \mathrm{E}-1$ & -- & 43 \\
\hline 128 & 31 & $>42$ & 29 & $1 \mathrm{E}-6$ & $<1 \mathrm{E}-10$ & $1 \mathrm{E}-7$ & 15 \\
\hline 129 & 2.0 & 2.0 & 3.3 & $1 \mathrm{E}-2$ & $1 \mathrm{E}-2$ & $1 \mathrm{E}-4$ & 5.0 \\
\hline 130 & 27 & 20 & 27 & $1 \mathrm{E}-2$ & $1 \mathrm{E}-2$ & $1 \mathrm{E}-2$ & 26 \\
\hline 131 & 6.4 & 11 & 14 & $1 \mathrm{E}-2$ & $1 \mathrm{E}-4$ & $1 \mathrm{E}-4$ & 8.7 \\
\hline 132 & 64 & -- & 130 & $1 \mathrm{E}-2$ & -- & $1 \mathrm{E}-1$ & 58 \\
\hline 133 & 270 & 240 & 170 & $1 \mathrm{E}-5$ & $1 \mathrm{E}-5$ & $1 \mathrm{E}-4$ & 150 \\
\hline 134 & .66 & 1.1 & 2.5 & $1 \mathrm{E}-2$ & $1 \mathrm{E}-3$ & $1 \mathrm{E}-6$ & 1.9 \\
\hline 139 & 4.8 & 6.4 & 3.8 & $1 \mathrm{E}-2$ & $1 \mathrm{E}-3$ & $1 \mathrm{E}-2$ & 7.5 \\
\hline 140 & -- & .19 & .79 & -- & $1 \mathrm{E}-2$ & $1 \mathrm{E}-6$ & .56 \\
\hline 141 & 1.6 & 1.5 & 1.8 & $<1 \mathrm{E}-7$ & $1 \mathrm{E}-7$ & $1 \mathrm{E}-6$ & .97 \\
\hline 142 & 10 & 5.2 & 15 & $2 \mathrm{E}-3$ & $1 \mathrm{E}-3$ & $1 \mathrm{E}-4$ & 5.6 \\
\hline 143 & .74 & 1.0 & 1.8 & $1 \mathrm{E}-2$ & $1 \mathrm{E}-3$ & $1 \mathrm{E}-6$ & 1.6 \\
\hline
\end{tabular}

* Tests 127 and $127 \mathrm{~b}$ are tests of the same well on different dates.

${ }^{a}$ Klusman, 1999; Picking, 1994.

b Cooper and others, 1967; Papadopulos and others, 1973.

${ }^{c}$ Mishra and Chachadi, 1985. 


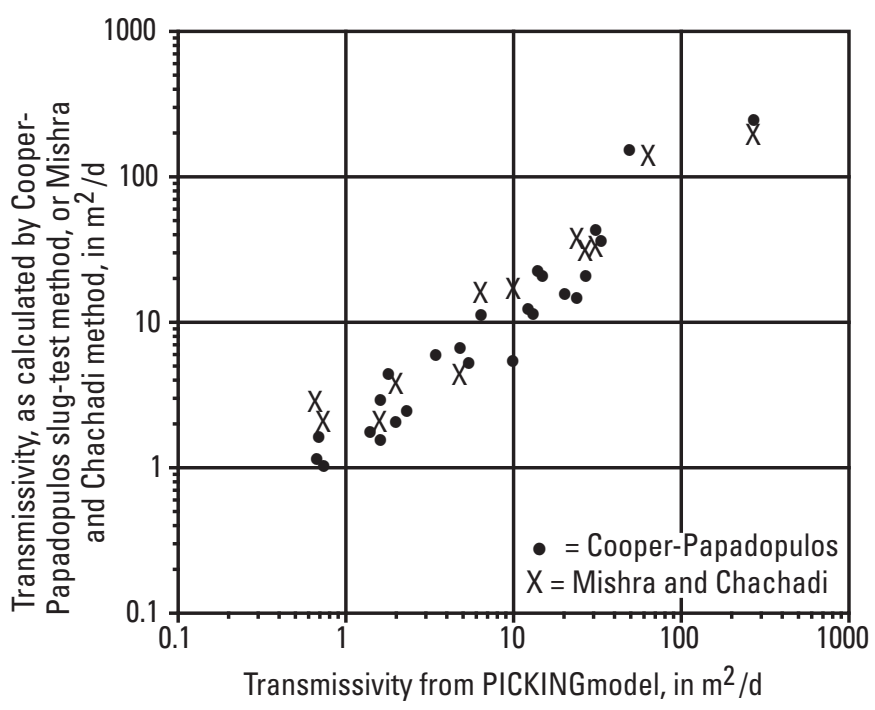

Figure 3. Comparison of transmissivity values from PICKINGmodel to those calculated from Cooper-Papadopulos slug-test method and Mishra and Chachadi method.

\section{Aquifer Nonhomogeneity or Boundaries}

Test data from several wells matched type curves for each analytical model for at least several thousand seconds. More commonly, however, the data points systematically rose above or fell below the type curve after the first 20 to 400 seconds of recovery. These departures may reflect what would be termed boundaries in classic image-well analysis (Ferris and others, 1962); that is, data points above a type curve imply anomalously slow recovery, which could result if one or more productive fractures intersected the well but pinched out, narrowed, or blended into a network of lesser fractures some distance from the well, as documented by comprehensive tests at a site in Connecticut (Gernand and Heidtman, 1997). Karasaki and others (1988) calculated that the slug-test type curves of Cooper and others (1967), which are similar to the PICKINGmodel type curves, would progressively steepen or plunge if a linear or radial constant-head boundary were postulated at progressively shorter distances from the tested well. They also illustrated several type curves that were custom-designed to represent slug-test responses to different idealized fracture geometries, which suggests that it may be possible to design an iterative process that could modify type curves to match a variety of observed data distributions. Alternatively, if brief tests of multiple wells in some locality are to be used to characterize aquifer transmissivity or hydraulic conductivity, some adjustment of test results to allow for apparent boundary effects may be advisable.

\section{Partial Penetration}

All three analytical methods described in this paper assume a well that fully penetrates a confined aquifer. Transmissivity calculated for such a well may be divided by the thickness of saturated bedrock penetrated to obtain average hydraulic conductivity of an equivalent porous medium. Confined conditions were inferred at the sites tested because the bedrock surface is capped by till, almost all water levels were above that surface, and water generally entered from fractures below unproductive rock. The wells do not fully penetrate the aquifer, in that additional water could presumably be obtained by drilling deeper. Nevertheless, Hyder and others (1994) concluded that violation of the assumption of full penetration would not significantly inflate hydraulic conductivity estimated by methods based on Cooper and others (1967) if aspect ratios (length of saturated bedrock penetrated, divided by well radius) exceeded 250 , or if hydraulic conductivity were appreciably greater horizontally than vertically. Most of the wells tested for this paper have aspect ratios of 600 or more, and anisotropy is likely because bedding-plane fractures typically are the chief paths of ground-water flow in sedimentary bedrock (Johnston, 1964; Heisig, 1999); therefore, the test results should not be seriously distorted by partial penetration.

\section{Summary}

Spatial or statistical variability in transmissivity of bedrock aquifers can be estimated from brief tests of the numerous domestic wells in many rural or suburban localities. The least disruptive (and hence most easily arranged) test method is to measure water levels frequently during one normal operating cycle of the owner's pump, which typically lasts about a minute, and for 30 minutes thereafter. Because such tests lower water levels only 1.5 to 2.5 meters, well loss caused by turbulent flow in bedrock fractures is likely to be much less than in longer tests with larger withdrawals.

These brief pumping tests can readily be analyzed by a new computer program by Klusman (2004, based on the method of Picking, 1994) that does not require measuring the rate or volume of withdrawal. Transmissivity values computed by this program are similar to those computed by two alternative methods (the Cooper-Papadopulos slug-test method, after extrapolation of recovery data to estimate the time and volume of a slug equivalent to the actual pumping, and the less convenient method of Mishra and Chachadi, 1985). All these methods yield approximate estimates of transmissivity that are applicable only to small areas near the pumped well, but are not sensitive to partial penetration. Storativity estimates may be qualitatively interpretable but are unlikely to accurately represent the bedrock aquifer. 


\section{References Cited}

Booth, C.J., 1988, Interpretation of well and field data in a heterogenous layered aquifer setting, Appalachian Plateau: Ground Water, v. 26, no. 5, p. 596-606.

Cooper, H.H., Jr., Bredehoeft, J.D., and Papadopulos, I.S., 1967, Response of a finite-diameter well to an instantaneous charge of water: Water Resources Research, v. 3, no. 1, p. 263-269.

Ferris, J.G., Knowles, D.B, Brown, R.H., and Stallman, R.W., 1962, Theory of aquifer tests: U.S. Geological Survey Water-Supply Paper 1536-E, 174 p.

Freeze, R.A., and Cherry, J.A., 1979, Groundwater: Englewood Cliffs, Prentice-Hall, 604 p.

Gernand, J.D., and Heidtman, J.P., 1997, Detailed pumping test to characterize a fractured bedrock aquifer: Ground Water, v. 35, no. 4, p. 632-637.

Heisig, P.M., 1999, Water resources of the Batavia Kill basin at Windham, Greene County, N.Y.: U.S. Geological Survey Water-Resources Investigations Report 98-4036, 96 p.

Hyder, Z., Butler, J.J. Jr., McElwee, C.D., and Liu, W.Z., 1994, Slug tests in partially penetrating wells: Water Resources Research, v. 30, no. 11, p. 2945-2957.

Johnston, R.H., 1964, Ground water in the Niagara Falls area, New York, with emphasis on the water-bearing characteristics of the bedrock: New York State Water Resources Commission Bulletin GW-53, 93 p.

Karasaki, K., Long, J.C.S., and Witherspoon, P.A., 1988, Analytical models of slug tests: Water Resources Research, v. 24, no. 1, p. 115-126.
Klusman, Kate, 1999, Determination of transmissivities of bedrock in the Appalachian Plateau as determined from low-stress pumping tests: Troy, N.Y., Rensselaer Polytechnic Institute, Ms. thesis, 77 p.

Klusman, Kate, 2004, A procedure for automated analysis of pumping tests of domestic wells: Ground Water, v. 42, no. 6, p. $945-948$.

Klusman, Kate and Randall, A.D., 2004, Documentation of PICKINGmodel computer program: program code and data sets posted on the World Wide Web October 1, 2004 at http://ny.usgs.gov/projects/pickingmodel/.

Kruseman, G.P. and deRidder, N.A., 1990, Analysis and evaluation of pumping test data: ILRI publication 47, The Netherlands, $377 \mathrm{p}$.

Mishra, G.C., and Chachadi, A.G., 1985, Analysis of flow to a large-diameter well during the recovery period: Ground Water, v. 23, no. 5, p. 646-651.

Papadopulos, I.S., and Cooper, H.H., 1967, Drawdown in a well of large diameter: Water Resources Research, v. 3, no. 1 , p. 241-244.

Papadopulos, I.S., Bredehoeft, J.D., and Cooper, H.H., 1973, On the analysis of slug-test data: Water Resources Research, v. 9, no. 4, p. 1087-1089.

Picking, L.W., 1994, Analyzing the recovery of a finitediameter well after purging at an unknown rate - a substitute for slug testing: Ground Water, v. 32, no. 1, p. 91-95.

Tiedeman, C.R., and Hsieh, P.A., 2001, Assessing an openwell aquifer test in fractured crystalline rock: Ground Water, v. 39, no. 1, p. 68-78. 
8 Analysis of Minimally Disruptive Brief Pumping Tests of Domestic Wells Completed in Bedrock in the Appalachian Plateau of New York

Table 1A. Transmissivity and storage coefficients as calculated from pumping tests of 26 bedrock wells in the Appalachian Plateau of New York by three computational methods, in English units.

$\left[\mathrm{ft}^{2} / \mathrm{d}\right.$, feet squ

\begin{tabular}{|c|c|c|c|c|c|c|c|}
\hline \multirow[t]{2}{*}{ Test * } & \multicolumn{3}{|c|}{ Transmissivity, in $\mathrm{ft}^{2} / \mathrm{d}$} & \multicolumn{3}{|c|}{ Storage coefficient } & \multirow{2}{*}{$\begin{array}{c}\text { Specific } \\
\text { capacity, in } \\
\text { (gal/min)/ft }\end{array}$} \\
\hline & $\begin{array}{l}\text { PICKING } \\
\text { model }^{a}\end{array}$ & $\begin{array}{c}\text { Cooper \& } \\
\text { Papadopulos }{ }^{b}\end{array}$ & $\begin{array}{c}\text { Mishra \& } \\
\text { Chachadi c }\end{array}$ & $\begin{array}{l}\text { PICKING } \\
\text { model }^{a}\end{array}$ & $\begin{array}{c}\text { Cooper \& } \\
\text { Papadopulos }\end{array}$ & $\begin{array}{c}\text { Mishra \& } \\
\text { Chachadi }^{\text {c }}\end{array}$ & \\
\hline 1 & 37 & 63 & - & $1 \mathrm{E}-2$ & $1 \mathrm{E}-4$ & - & 0.49 \\
\hline 2 & 7.3 & 17 & - & $1.5 \mathrm{E}-1$ & $1 \mathrm{E}-2$ & - & 0.28 \\
\hline 3 & 350 & 390 & - & $1 \mathrm{E}-7$ & $1 \mathrm{E}-7$ & - & 1.4 \\
\hline 101 & 25 & 26 & - & $1 \mathrm{E}-3$ & $1 \mathrm{E}-3$ & - & 0.24 \\
\hline 103 & 520 & 1500 & - & $1 \mathrm{E}-2$ & $1 \mathrm{E}-10$ & - & 3.1 \\
\hline 105 & 160 & 220 & - & $1 \mathrm{E}-5$ & $1 \mathrm{E}-7$ & - & 0.80 \\
\hline 106 & 150 & 240 & - & $1 \mathrm{E}-4$ & $1 \mathrm{E}-7$ & - & 0.90 \\
\hline $107 \mathrm{~b}$ & 140 & 120 & - & $1 \mathrm{E}-4$ & $1 \mathrm{E}-3$ & - & 0.90 \\
\hline 108 & 58 & 55 & - & $1 \mathrm{E}-5$ & $1 \mathrm{E}-5$ & - & 0.32 \\
\hline $109 \mathrm{~b}$ & 130 & 130 & - & $1 \mathrm{E}-2$ & $1 \mathrm{E}-2$ & - & 1.3 \\
\hline $110 \mathrm{~b}$ & 17 & 30 & - & $5 \mathrm{E}-1$ & $1 \mathrm{E}-1$ & - & 1.0 \\
\hline 115 & 19 & 46 & - & $7 \mathrm{E}-2$ & $1 \mathrm{E}-3$ & - & 0.40 \\
\hline 116 & 15 & 18 & - & $4 \mathrm{E}-3$ & $1 \mathrm{E}-3$ & - & 0.22 \\
\hline 127 & 260 & 150 & 360 & $>5 \mathrm{E}-1$ & $5 \mathrm{E}-1$ & $1 \mathrm{E}-1$ & 4.3 \\
\hline $127 \mathrm{~b}$ & 220 & 160 & - & $5 \mathrm{E}-1$ & $5 \mathrm{E}-1$ & - & 3.5 \\
\hline 128 & 330 & $>450$ & 310 & $1 \mathrm{E}-6$ & $<1 \mathrm{E}-10$ & $1 \mathrm{E}-7$ & 1.2 \\
\hline 129 & 22 & 22 & 36 & $1 \mathrm{E}-2$ & $1 \mathrm{E}-2$ & $1 \mathrm{E}-4$ & 0.40 \\
\hline 130 & 290 & 220 & 290 & $1 \mathrm{E}-2$ & $1 \mathrm{E}-2$ & $1 \mathrm{E}-2$ & 2.1 \\
\hline 131 & 69 & 120 & 150 & $1 \mathrm{E}-2$ & $1 \mathrm{E}-4$ & $1 \mathrm{E}-4$ & 0.70 \\
\hline 132 & 690 & - & 1300 & $1 \mathrm{E}-2$ & - & $1 \mathrm{E}-1$ & 4.7 \\
\hline 133 & 2900 & 2600 & 1800 & $1 \mathrm{E}-5$ & $1 \mathrm{E}-5$ & $1 \mathrm{E}-4$ & 12 \\
\hline 134 & 7.1 & 12 & 27 & $1 \mathrm{E}-2$ & $1 \mathrm{E}-3$ & $1 \mathrm{E}-6$ & 0.15 \\
\hline 139 & 52 & 69 & 41 & $1 \mathrm{E}-2$ & $1 \mathrm{E}-3$ & $1 \mathrm{E}-2$ & 0.60 \\
\hline 140 & - & 2.0 & 8.5 & - & $1 \mathrm{E}-2$ & $1 \mathrm{E}-6$ & 0.045 \\
\hline 141 & 17 & 16 & 19 & $<1 \mathrm{E}-7$ & 1E-7 & $1 \mathrm{E}-6$ & 0.078 \\
\hline 142 & 110 & 56 & 160 & $2 \mathrm{E}-3$ & $1 \mathrm{E}-3$ & $1 \mathrm{E}-4$ & 0.45 \\
\hline 143 & 8.0 & 11 & 19 & $1 \mathrm{E}-2$ & $1 \mathrm{E}-3$ & $1 \mathrm{E}-6$ & 0.13 \\
\hline
\end{tabular}

* Tests 127 and $127 \mathrm{~b}$ are tests of the same well on different dates.

${ }^{a}$ Klusman, 1999; Picking, 1994.

${ }^{\text {b }}$ Cooper and others, 1967; Papadopulos and others, 1973.

${ }^{\mathrm{c}}$ Mishra and Chachadi, 1985. 